\title{
É CARNAVAL NO RECIFE DE 1985, A ALEGRIA É QUE IMPERA! Oh que beleza, tem festa, tem magia e tem mãe Badia nesta folia!
}

Augusto Neves Silva*

RESUMO: Este trabalho analisa as relações históricas entre a mãe de santo Badia e o Carnaval do Recife de 1985. Buscamos entender os caminhos que levaram essa personagem a tornar-se símbolo do Carnaval recifense. Para tanto, procura-se compreender como, em torno da figura de Badia, é possível vislumbrar discussões relevantes sobre tradição, festas, religiosidade popular, identidade e cultura negra no Recife. Interpretar os caminhos desse acontecimento é possibilitar conhecer um pouco mais a respeito de memórias invisualizadas sobre o Carnaval recifense e sobre a própria capital pernambucana.

PALAVRAS-CHAVE: Festejos carnavalescos; Carnaval recifense; Mãe de Santo Badia; Cultura Negra; História do Recife.

\section{It's Carnival time in Recife in 1985 -joy reigns! Oh, what a beauty! There is partying, there is magic, and Mother Badia in this revelry!}

ABSTRACT: This article seeks to analyze the historical relations between the priestess ("Mãe-desanto") Badia and the Carnival of Recife of 1985. We aim to understand how this person came to be the symbol of Recife's Carnival. For this, we try to perceive how around Badia's figure one can discern relevant discussions on tradition, parties, popular religion, identity and black culture in Recife. Understanding the possibilities of the aforementioned event is to be able to learn more about the invisible memories of the Carnival of Recife and the capital of Pernambuco itself.

KEYWORDS: Carnival; Brazilian Carnival; Carnival of Recife; "Mãe-de-santo" Badia; Black culture; History of Recife.

\section{¡Carnaval de Recife en 1985, reina la alegría! ¡Oh que maravilla, hay fiesta, hay magia y está madre Badia en esta juerga!}

RESUMEN: Este trabajo analiza las relaciones históricas entre la madre de santo Badia y el Carnaval de Recife en 1985. Buscamos comprender como ella se convirtió en un símbolo de los Carnavales de Recife. Por lo tanto, tomando como punto de partida la persona de Badia, intentamos plantear cuestiones sobre la tradición, fiestas, religiosidad popular, la identidad y la cultura negra en Recife. Interpretar las formas de este evento nos permite conocer un poco más sobre las memorias que no tienen visibilidad en la historia de los Carnavales de la capital de Pernambuco.

PALABRAS-CLAVE: Fiestas de Carnavales; Carnavales de Recife; Madre de santo Badia; Cultura negra; Historia de Recife.

\footnotetext{
*Mestre em História pelo Programa de Pós-Graduação em História da Universidade Federal de Pernambuco (UFPE), e doutorando no Programa de Pós-Graduação em História da Universidade Federal Fluminense (UFFRJ). Email: augustonev@gmail.com
} 


\section{Abram alas, deixem-na passar!}

Em minhas pesquisas sobre o Carnaval do Recife, inúmeras figuras aparecem na documentação como sujeitos emblemáticos da festa. São aquelas que as fontes nomeiam como importantes ou mesmo as que ocupam o "lugar do tradicional" na memória coletiva. ${ }^{1}$

Nesse processo, uma personagem em especial vem chamando minha atenção. Haja vista que em torno dela se aglutinam temas que ajudam muito a pensar as construções identitárias elaboradas a respeito da folia de momo recifense, bem como da cultura negra local. $^{2}$

Por meio da análise dessa personagem, pode-se compreender o cenário de uma época e interpretar como se estabeleceu uma complexa rede de vínculos de pertencimentos e de representatividade, bem como investigar de que forma, em torno dela, emergiram discussões a respeito de temas como "tradição", "cultura negra", "memória" e "religiosidade popular".

O Carnaval do Recife de 1985 foi em sua homenagem. Um dos motivos para tal feito foi que, em torno da sua imagem, aspectos do popular retornariam a folia momesca local. ${ }^{3}$ Diante dessas questões, elegi para este trabalho a figura de Maria de Lourdes da Silva, conhecida como Badia. ${ }^{4}$

Os dias de folia de 1985 foram nomeados como "Carnaval de Badia". Homenagens e cerimônias à nossa personagem marcaram a festa. O objetivo dos membros da Fundação de Cultura do Recife foi o de "reconhecer e ressaltar todos os esforços, dedicação e amor ao Carnaval de sua foliã símbolo". 5

O prefeito Joaquim Francisco atendendo sugestão da Fundação de Cultura do Recife, decidiu dedicar o Carnaval do Recife de 1985 a uma das suas mais tradicionais, populares e estimadas foliã, Badia, considerada uma espécie de madrinha de todas as agremiações. ${ }^{6}$

Maria de Lourdes da Silva, conhecida como Badia, foi uma mãe de santo. Sua casa localizava-se no Pátio do Terço - lugar de relevância para as manifestações associadas aos negros em Recife. Badia gostava de intitular-se "costureira de Carnaval" e participava de várias agremiações carnavalescas, entre elas a escola de samba Estudantes de São José, o bloco Verdureiras de São José e o clube Vassourinhas. Entretanto, não buscou construir sua imagem associada a nenhum grupo e afirmava "amar todas as agremiações". 7

Uma das perguntas centrais desse trabalho é tentar entender as relações que permitiram a Maria de Lourdes da Silva, uma mãe de santo, negra, pobre, mulher simples ${ }^{8}$ tornar-se símbolo e figura central de uma das mais importantes festas populares do Recife, o 
Carnaval. Não tenho por objetivo - não só pelos limites desse trabalho, mas também pela complexidade do tema - estabelecer uma biografia histórica de Badia. O que me proponho é contar um pouco de sua trajetória ${ }^{9}$, ler nas matérias de jornais e em alguns (poucos) trabalhos historiográficos que discutiram sua figura que Badia estava sendo construída e representada por esses discursos.

Uma segunda proposta é interpretar algumas publicações de periódicos sobre o Carnaval do Recife de 1985. Buscar compreender o que os jornalistas elegeram como evidente da festa, tentando, assim, construir uma imagem sobre o Carnaval daquele ano que se identificasse com a proposta do órgão oficial que a dirigia, a Fundação de Cultura da Cidade.

Portanto, espero ter deixado claros os motivos que me levaram a escrever este trabalho. Desejo que ao continuar a leitura, o leitor e a leitora, principalmente aqueles e aquelas que não conhecem o Carnaval do Recife, reflitam sobre uma série de questões que são colocadas como naturais sobre essa festa, mas que ainda têm muito a nos contar sobre as lutas cotidianas, os embates políticos e as disputas pela construção das memórias. Saliento ainda que mesmo aqueles leitores e leitoras que não são foliões podem encontrar nos dias de folia uma ótima oportunidade para pensar os conflitos sociais, pois as festas nos ajudam muito a pensar o Brasil.

\section{Badia e as Tias do Terço: diálogos entre África e Brasil}

Segundo as matérias de jornais ${ }^{10}$, Badia nasceu na Rua Augusta, no Bairro de São José, no Recife, em 1915. Sua mãe (figura desconhecida) era lavadeira e trabalhava numa lavanderia que funcionava no Pátio do Terço, ${ }^{11}$ na casa das Tias. Nesse pátio localizava-se uma casa de Xangô ${ }^{12}$ que durante muito tempo foi coordenado por algumas mulheres que receberam a nomeação de Tias, as Tias do Terço.

Desde criança Badia foi deixada por sua mãe aos cuidados das Tias, Vivina Rodrigues Braga e Emília Duarte Rodrigues. ${ }^{13} \mathrm{Na}$ casa destas, nossa personagem foi criada e lá entrou em contato com as especialidades das "artes e terapias mágico-religiosas - às vezes simplesmente medicinais - herdadas da África, da Ibéria e de outras áreas da Europa". ${ }^{14}$

Badia nasceu e viveu no Pátio do Terço. Afirmava também "ter nascido e crescido no santo, ou seja, na religião dos orixás". ${ }^{15}$ De acordo com as pesquisas realizadas pelos 
antropólogos Roberto Motta e Maria do Carmo Brandão, assim pode ser definida a memória da presença das Tias no Recife:

[...] Eugênia Duarte Rodrigues foi à primeira das Tias conhecidas. Casou-se com Joaquim Duarte Rodrigues e teve duas filhas. Vivina Rodrigues Braga era a primogênita e ficou conhecida como Sinhá, era filha de Xangô. Nascida em 1867 e falecida em 1966. A segunda filha, Emília Duarte Rodrigues, Yayá. Era filha de Oxum, nasceu em 1870 e morreu em 1968. Badia, Maria de Lourdes da Silva, sucessora das Tias Sinhá e Yayá, nasceu em 1915 e não era parenta consanguínea de ambas. Ao que parece, esse fato lhe negava a condição de Tia [...]. ${ }^{16}$

Independentemente de atribuir aqui veracidade ou não a essa história, o importante é interpretar os sentidos contidos em torno dela. Acredito que esse acontecimento funciona quase como um "mito fundador" para explicar a presença e a importância de Badia na cidade. De acordo com os relatos dos antropólogos acima citados, essa história é recorrente naquilo que nomeiam de "tradição das práticas denominadas de afro-brasileiras no Recife".

Mesmo sabendo da impossibilidade de se encontrar a origem, é importante analisar como as pessoas tomam esse discurso e como constroem sobre ele significados. E é nesse sentido que busco analisar esse acontecimento, pois foi em torno dessa memória que Badia foi construída no Recife.

As relações com a casa das Tias lhe deram a sustentação do "lugar da tradição" que ela ocupou (e ocupa, em outros sentidos) na capital pernambucana. Badia "representa a continuidade, a tradição e até, com as restrições que se fizeram ao termo, a 'burocracia' do xangô". ${ }^{17}$ Ou seja, o espaço comandado por Badia representa a ligação com a tradição, com a "autenticidade" das práticas religiosas do Xangô em Pernambuco. ${ }^{18}$

A relação com a África no processo de formação das culturas norte-americanas sempre constituiu a questão central dos estudos científicos sobre os negros. A força variável das "sobrevivências africanas", também chamadas de "africanismos", no seio das diferentes culturas negras no continente, está na origem de teorias, mais ou menos elaboradas, que ordenam essas culturas segundo sua proximidade, real ou imaginária, com a África. ${ }^{19}$

Alguns pesquisadores ${ }^{20}$ chegam a afirmar que a casa de Badia, juntamente com o terreiro de Pai Adão ${ }^{21}$, representa o fundamento ${ }^{22}$ da religião afro-brasileira no Recife. Os estudos a respeito do Xangô pernambucano ainda carecem de estudos, poucos trabalhos se aventuraram em tomar essa temática como foco de suas análises, principalmente durante o século $\mathrm{XIX}^{23}$ : "O surgimento do xangô propriamente dito, como religião autônoma ainda que 
conservando (como até hoje conserva) vínculos sincréticos com o catolicismo, é praticamente contemporâneo ao surgimento da ciência social em nosso país". ${ }^{24}$

Os debates em torno da presença da África na cultura desenvolvida pelos negros e negras na América passam por dois vieses. O primeiro deles é marcado pela perda das raízes culturais e inclui os Estados Unidos, o outro caracterizado pela preservação das culturas africanas, ao qual pertencem Cuba e Brasil. ${ }^{25}$

Alguns autores questionaram as conclusões reducionistas que se resumem em explicar a partir da localidade o lugar da tradição. Paul Gilroy, em seu livro "O Atlântico Negro"26, lançou mão do conceito de diáspora para romper com esses laços explicativos entre posição, espaço e consciência. Para o autor, o território não pode servir para determinar a identidade. Diante disso, não compartilha de uma identidade enraizada, autêntica, natural e estável. O referido sociólogo inglês destaca que as "culturas e identidades negras são indissociáveis da experiência da escravidão moderna e de sua herança racializada espalhada pelo atlântico". ${ }^{27}$

A procura por esses africanismos marcaram o pensamento de Herskovits quando este buscou "provar" a presença da África na América. Para o referido autor, os negros que vieram para a América trouxeram muitas de suas práticas que permaneceram inalteráveis e contribuíram significativamente para a construção de uma identidade negra no Novo Mundo. ${ }^{28}$ Ou seja, Herskovits procurou mostrar como os povos africanos contribuíram, de forma latente, para a construção de uma cultura americana.

[...] sua análise não visava mostrar que os "africanismos" eram reproduzidos identicamente, mas como o encontro entre africanos, europeus e ameríndios havia acarretado uma adaptação e uma integração cultural. [...] O destaque dado aos africanismos foi, portanto, a resposta ao ponto de vista etnocêntrico que quer que toda cultura "inferior" posta em contato com a cultura europeia, desapareça. ${ }^{29}$

De acordo com Peter Wade muitos autores "criticaram o conceito herskovitsiano da simples sobrevivência de determinados traços culturais africanos, que persistiriam mais ou menos inalterados nos contextos americanos". ${ }^{30} \mathrm{Em}$ vez de seguir essa vertente, Wade afirma que prefere a ideia de "orientação cognitiva",31 para ligar a África e a América: "Tal visão sugere que os povos africanos do Novo Mundo compartilhavam alguns princípios culturais básicos, alguns valores e modos de pensar que moldaram a maneira como eles desenvolveram novas formas culturais nas Américas". ${ }^{32}$

Ainda sobre a concepção de africanismos, Wade destaca que aquilo que se nomeia como tal tem variado historicamente: "Essas categorias foram discursivamente construídas de 
maneiras complexas, e não é fácil separarmos os africanismos 'como tais' do modo como as pessoas percebem e falam da negritude e da África". ${ }^{33} \mathrm{Na}$ América Latina, África tem sido não só parte da construção da cultura negra, da cultura popular e de um novo sistema religioso sincrético, mas também do imaginário associado à nação moderna e, em geral, à modernidade e ao Modernismo. ${ }^{34}$

As construções em torno de Badia buscaram associar sua imagem à presença da África. Era lhe dado o lugar da tradição religiosa pela presença desses africanismos. Badia representava a legitimidade e a autenticidade do que era nomeado como religião dos africanos, que era praticada no Recife da década de 1980. E Badia soube aproveitar-se dessa questão.

Badia dispunha-se a receber quem a procurasse, bem entendido que sob a condição como qualquer outro psicoterapeuta - de que o cliente pudesse arcar com os honorários (que haveriam de variar de acordo com sua condição socioeconômica) e, para a solução completa do problema, que estivesse disposto a cumprir as prescrições determinadas pelos búzios e pela sagacidade da ialorixá. ${ }^{35}$

Badia tinha importante influência entre os comerciantes do Bairro de São José. Era uma magopsicoterapeuta de relevante importância na cidade do Recife. De acordo com a entrevista do sambista Valdeck Mello "a casa de Badia estava sempre cheia de gente, que ia procurar os seus serviços espirituais". ${ }^{36} \mathrm{O}$ espaço era frequentado por comerciantes, políticos e inúmeras outras pessoas que vinham de perto e de longe para consultas. Durante muitos anos ela soube tirar proveito da visibilidade que possuía e do lugar de autoridade religiosa que lhe era dado.

\title{
Badia é de festa, é de religião!
}

\author{
Ô Mãe Badia \\ Filha da Oxum \\ Aê, êô \\ Menina Oxum aê, êô \\ Filha do céu pra gente vê \\ (Rivaldo Pessoa) $^{37}$
}

As representações ${ }^{38}$ construídas em torno da figura de Badia a relacionam com dois outros acontecimentos (além do Carnaval) de suma importância para a história do povo negro no Recife. Trata-se da Noite dos Tambores Silenciosos e da Sociedade de São Bartolomeu.

A Noite dos Tambores Silenciosos é um acontecimento que ocorre na segunda-feira de Carnaval. Teve início nos anos de 1960 pela iniciativa de figuras que lutavam em defesa de 
uma identidade negra no Recife, o jornalista Paulo Vianna e a Ialorixá Maria de Lourdes da Silva (a nossa Badia!).

A ideia da cerimônia surgiu a partir da homenagem que as nações de maracatu prestavam aos orixás, por ocasião do Carnaval, diante do Axé das Tias, onde as calungas, representantes dos ancestrais, dançavam. Para retribuir a honraria e homenagear os maracatus e seu simbolismo, Badia se empenhou em garantir esse encontro cerimonial que hoje integra a programação oficial do Carnaval pernambucano, sendo visto como um de seus momentos mais sublimes. ${ }^{39}$

O evento Noite dos Tambores Silenciosos está intimamente relacionado ao Pátio do Terço, este se constitui como um lugar sagrado para as religiões dos negros e das negras no Recife, pois ali se estabelece uma série de trocas culturais que lhe dão sentido religioso, social e simbólico. Badia é uma das figuras importantes da história dos negros e negras no Recife e está associada à criação do evento Noite dos Tambores Silenciosos. O pátio do Terço, onde se localizava a casa de Badia, aos poucos foi se configurando num importante espaço para a celebração e homenagens aos antepassados do "povo do santo".

O evento é fruto de uma criação do jornalista PauloViana, que o concebeu como uma forma de homenagear o encontro entre a rainha Dona Santa, do Maracatu Nação Elefante, e as “mães pretas” Sinhá e Yayá, mulheres de idade avançada e que praticavam, segundo rezam as memórias, a religião dos orixás. $\mathrm{O}$ evento surge como forma de fazer esta homenagem, e ao mesmo tempo celebrar os antepassados, os escravos que morreram na travessia do continente africano para o Brasil, bem como aqueles que faleceram nestas terras. As primeiras notícias sobre este evento ocorrem sob este contexto, ou seja, a coroação da Rainha Dona Santa, e de uma homenagem à mesma, a ser feita por Joãozinho Dagoméia, babalorixá baiano (e residente no Rio de Janeiro) considerado pela imprensa como "rei do candomblé". ${ }^{40}$

De acordo com as pesquisas da historiadora Isabel Guillen, a Noite dos Tambores Silenciosos foi ao longo dos anos adquirindo outros significados que não estavam presentes em seu início na década de 1960, "apesar de já nesta data apresentar o caráter de rememoração da escravidão". ${ }^{41}$

[...] a Noite dos Tambores Silenciosos, evento que ocorre na segunda-feira de Carnaval do Pátio do Terço, e que ao longo dos anos tem sido assumido pelos movimentos políticos e culturais de grupos de afrodescendentes como um grande ritual de congraçamento e celebração de cultura afro no Recife. É marcadamente um evento de cunho religioso e não haveria exagero se o apontássemos como um ritual de maior visibilidade que as religiões consideradas de matriz africana conseguem lançar para a sociedade. ${ }^{42}$ 
Guillen alerta ainda sobre a necessidade de novas pesquisas sobre o evento da Noite dos Tambores Silenciosos: "Suas dificuldades e persistência são temas que merecem um estudo detalhado para se entender como ao longo da década de noventa torna-se um dos eventos mais concorridos do Carnaval recifense". ${ }^{43}$

Outro acontecimento importante ligado à trajetória de Badia é a Sociedade de São Bartolomeu, a qual era presidida pela afamada mãe de santo: "Não se pode compreender Badia e seu assentamento no Bairro de São José sem levar em conta a famosa e misteriosa Sociedade de São Bartolomeu, que se reunia periodicamente em sua casa". ${ }^{44}$ Cabe ressaltar aqui que São Bartolomeu é um santo sincretizado com Exu. De acordo com Motta e Brandão, Badia exercia uma importante influência entre os comerciantes do Bairro de São José. Essa liderança afirmava-se, em parte, por meio da Sociedade de São Bartolomeu, a qual tinha em Badia umas das suas principais figuras: "Daí o grande, o enorme prestígio político de Badia, com o qual muitos poucos, no campo das religiões afro-pernambucanas, podiam rivalizar, muito menos superar". 45

A festa de São Bartolomeu era comumente realizada no mês de outubro, momento que coincidia com a famosa Festa do Inhame, de forte tradição Nagô.

Era durante esse mês que Badia oferecia seu Bori (ou ebori) e patrocinava os grandes sacrifícios. Tudo realizado na maior reserva, na presença de dois ou três babalorixás distintos e de mais umas poucas pessoas íntimas e consideradas especialíssimas. Tanto que os pesquisadores que relataram esta passagem eram dois dos poucos escolhidos para participar de ato tão solene e discreto. ${ }^{46}$

O sambista Valdeck Mello recorda-se com alegria de como eram feitas as festas na casa de Badia:

Amanhã é dia de São Bartolomeu, aí hoje já começava a fazer as coisas de São Bartolomeu, o povo já bebendo, a rua iluminada, a casa pintada. Aí no outro dia, a festa mesmo. No terceiro dia tinha a feijoada ao meio dia, da sociedade, e à noite tinha eleição de novo. Era outra festa, era outro banquete. Era banquete em cima de banquete! E terminava sempre no outro dia. Às vezes quando terminava e não tinha mais dinheiro, entrava na cota de sacrifício. Que era a cota de sacrifício? Cada diretor dava... Quem tivesse lá... "Me dá um, me dá dois, me dá três...". "Vá buscar mais uma grade de cerveja". Aí emendava... ${ }^{47}$

Em entrevista à historiadora Zuleica Dantas, Raminho de Oxóssi ${ }^{48}$ (filho de santo de Badia) assim descreveu a atuação da casa das Tias e de Badia: tinha a..., São Bartolomeu. São Bartolomeu era um santo que ela tem um quadro, dia 
vinte e quatro de agosto ela levava o quadro pra igreja, faz uma missa e volta, faz uma obrigação. ${ }^{49}$

Badia apresentava-se como uma figura que tinha autoridade para falar em nome da tradição, daquilo que era entendido como cultura negra no Recife. De acordo com Jocélio Teles, é a partir dos anos de 1960 que se observam no Brasil discursos de valorização da cultura afro brasileira. Com isso Teles afirma: "aqueles que falam em nome dessa cultura" não só são intelectuais, como também lideranças afroreligiosas. ${ }^{50}$

Nesse sentido, Badia - como uma líder religiosa de grande popularidade no Recife pode ser compreendida como uma figura que representava o poder da cultura que nos fala Bourdieu. ${ }^{51}$ A pessoa de Badia serviu como um elemento importante para as definições do que é nomeado de práticas negras no Recife.

Como afirma Magdalena Almeida, o conhecimento que se tem da vida de Badia não é igual ao das outras Tias, pois sobre ela sabe-se muito mais. Entretanto, não se pode deixar de levar em consideração que por meio da análise de sua trajetória é possível compreender que as suas ações foram resultados também de uma família a qual fez parte. ${ }^{52}$ Ou seja, dito de outra forma: a importância de Badia, em muitos aspectos, deve-se ao seu elo com as Tias "africanas" do pátio do terço em Recife. E nesse ínterim, como bem destacou Roberto Motta e Maria do Carmo Brandão, foi em torno dessa liderança - e obviamente da sua ligação com as agremiações carnavalescas - que a Fundação de Cultura da Cidade do Recife resolveu homenagear Badia com o Carnaval de 1985.

\section{Badia, a dona do Carnaval de 1985!}

Ô Mãe Badia

$\mathrm{O}$ teu sorriso iluminou

Nossa terra

Nossa mãe

(Rivaldo Pessoa)

As representações em torno do Carnaval do Recife o lançam ao lugar de uma das mais importantes festas do Brasil. Os dias de Momo na capital pernambucana estão presentes nas imagens e na memória de parcela consistente da população, pois a festa funciona como um importante momento para se compreender os conflitos em torno da identidade local.

Em 1985 a Fundação de Cultura da Cidade do Recife, sob a direção de Cussy de Almeida, decidiu homenagear a personagem desse trabalho, Maria de Lourdes da Silva, 
conhecida popularmente como Badia. A decisão do órgão público foi aceita pelo então prefeito do Recife, Joaquim Francisco.

Desde a criação da Fundação de Cultura do Recife em 1979, o objetivo das autoridades municipais era de promover a volta do que nomeavam de "Carnaval participação". Em que consistia esse Carnaval participação? Entendia-se por participação uma folia de Momo sem a separação entre público participante e público espectador. Não deveriam existir cordões de isolamento que separassem os desfilantes das agremiações e os demais foliões. Era a volta do que se chamava de Carnaval popular do Recife.

Durante a década de 1970, o Carnaval do Recife foi aos poucos assumindo ares de uma espetacularização. As agremiações deveriam enquadrar sua apresentação com o objetivo de agradar e atrair o público espectador. Dentro desse cenário de festa, as escolas de samba tornaram-se as grandes atrações da folia de Momo local. No entanto, enfrentaram duras críticas dos defensores de uma "legítima cultura pernambucana", na qual as escolas de samba não estavam incluídas. ${ }^{53}$

Assim, os representantes da Fundação de Cultura tinham como principal missão trazer o Carnaval do Recife de volta à sua "originalidade", ou seja, ao seu aspecto popular. E, nesse sentido, a homenagem a Badia - uma das principais figuras do Carnaval da cidade - foi um ótimo momento de fazer o Carnaval se reencontrar com sua tradição e sua "originalidade". ${ }^{54}$

[...] "O Carnaval da Badia vai ser o melhor do Brasil. Dedicando a folia de 85 a esta pessoa simples estamos homenageando a carnavalesca que durante décadas trabalhou no anonimato, costurando fantasias, estimulando as agremiações do bairro de São José, onde sempre viveu", declarou o prefeito Joaquim Francisco na noite da última sexta-feira quando abriu, oficialmente, o Carnaval do Recife. ${ }^{55}$

Os relatos sobre Badia anunciam que sua relação com o Carnaval foi muito antiga. Suas Tias foram uma das fundadoras do bloco Espanadores, depois passando a frequentar o clube Vassourinhas ${ }^{56}$. Sua casa era um reduto de carnavalescos.

No berço, a menina Badia já traquinava entre fantasias de plumas, cetins, lantejoulas e paetês. E aprendeu a conviver desde cedo com as artimanhas e segredos da folia. Aos 12 anos costurava para uma troça de criança, a "Fumaça não assa carne", dos Coqueiros. [...] Aprontou fantasias para todos os grandes clubes, blocos, escolas de samba e troças do Recife, e também para algumas pequenas agremiações. ${ }^{57}$

Badia gostava de intitular-se "costureira de Carnaval" e muitas das agremiações carnavalescas disputavam, ferrenhamente, quem a teria como costureira. 
Pão Duro, Prato Misterioso, Pão da Tarde, Vassourinhas, Batutas de São José, Madeiras do Rosarinho, Inocentes do Rosarinho, Estudantes de São José, entre outras, foram algumas das inúmeras agremiações que já brilharam e ganharam títulos de campeãs com as fantasias preparadas por Badia. Todos os anos, sempre a mesma coisa: verdadeiros apelos para que ela fosse destaque deste ou daquele conjunto, mas nunca aceitou. ${ }^{58}$

Sobre sua experiência como costureira de Carnaval, Badia destacava que, mesmo num cenário de luxo e ostentação, nunca conseguiu enriquecer materialmente: "É somente pelo gosto que a gente sente em ajudar as pessoas que desejam ficar bonitas, fantasiadas, para brincar. Quem costura com este espírito nunca enriquece materialmente, mas experimenta um prazer espiritual muito compensador". 59

Entretanto, Badia afirmava que não era muito foliã, gostava mesmo era de trabalhar nos bastidores da festa. Comparava o seu trabalho ao de uma artesã que, minuciosamente ia dando vida aos sonhos, desejos e anseios de centenas de pessoas.

É de mim mesma. Gosto de Carnaval, dou tudo de mim para que as pessoas se vistam da melhor maneira possível, mas este negócio de desfilar não é comigo. $\mathrm{O}$ que eu sempre quis foi aprontar as pessoas, fazê-las feliz com as fantasias mais bonitas e desejadas. $^{60}$

O Bairro de São José ainda figura como um dos principais polos de agremiações do Carnaval da cidade. Inúmeras delas carregam em seu nome referência ao bairro ou situam-se nele, tais como: Escola de Samba Estudantes de São José, bloco Verdureiras de São José, Clube Pierro de São José, troça Traquinas de São José, bloco de samba Saberé, bloco Donzelos, entre outros. Fato este que, de certa forma, coaduna com o discurso da importância do bairro como um lócus para o Carnaval da cidade.

A ligação de Badia com várias agremiações carnavalescas, talvez, esteja associada à sua relação com o bairro de São José. Durante muitos anos, esta localidade concentrou uma elevada quantidade de agremiações carnavalescas, além de ser um espaço de forte atividade comercial. Possuía aguda concentração populacional de indivíduos que trabalhavam no comercio e moravam no próprio bairro.

Algumas publicações de jornais trazem a informação, atribuída a Badia, que era no Bairro de São José que se vivia o "verdadeiro Carnaval participação". ${ }^{61}$ Outra matéria faz menção a uma crítica de Badia ao fato das agremiações deixarem de se apresentar, nem mesmo passarem pelo Pátio do Terço (localizado no Bairro de São José), "nos carnavais do passado, todo mundo vinha para cá, hoje não sei por que mudou". ${ }^{62}$ Talvez, por este fato, os 
representantes da Fundação de Cultura decidiram estabelecer o Pátio do Terço como o local de concentração de todas as agremiações desfilantes no Carnaval de 1985.

\begin{abstract}
A reativação do Carnaval do bairro de São José, fenômeno que vem se manifestando a cada ano, e que foi favorecido, ano passado, com o retorno da área do desfile das agremiações para a Av. Dantas Barreto, será muito maior, este ano, com a decisão da Fundação de Cultura da cidade do Recife em determinar como área de concentração de todas as desfilantes o Pátio do Terço, Rua de São João, Rua Padre Floriano e adjacências. ${ }^{63}$
\end{abstract}

Os jornais noticiaram que o Carnaval foi um tremendo sucesso. Quase todas as agremiações passaram em frente à casa de Badia e fizeram reverência à homenageada da festa: "Porta estandartes de vários clubes fizeram evoluções e reverências à figura popular mais respeitada da área. Ela, toda de branco, serena e altiva, agradecia emocionada" ${ }^{64}$

É interessante observar que as matérias destacadas pelo Diario de Pernambuco periódico que apoiava o governo municipal - mencionavam que o Carnaval de 1985 foi uma festa que se reencontrou com a sua dimensão histórica. A folia de Momo recifense estava de volta à sua originalidade, ao seu aspecto popular.

Sobre o Carnaval que homenageou Badia, qual a visão que a própria homenageada tinha da festa? Como ela via as mudanças das quais ela foi palco? De acordo com o Diario de Pernambuco, Badia via sem problemas as mudanças que ocorria na festa: "Se tudo mudou na vida, porque ficarmos lamentando que o Carnaval de agora não seja como o de antigamente. É impossível viver da reconstituição do passado. Carnaval é mistura, como antigamente" ${ }^{65}$

No entanto, de acordo com uma matéria destacada pelo Jornal do Commercio, Badia criticava as mudanças provocadas na festa, acreditava que o "verdadeiro Carnaval" estava morrendo com as transformações da modernidade: "A crise econômica, o desemprego e a angústia em que vive o nosso povo têm empanado os festejos de Momo que não são nem sombra do que eram no passado". ${ }^{66}$

Independente da homenagem a Badia no Carnaval de 1985, da relação que estabeleceu com várias agremiações carnavalescas, do lugar tradicional ocupado por ela - como um ícone da religião nomeada de afro-brasileira no Recife -, é importante se compreender as disputas em torno da memória que foi construída em torno de sua imagem. 


\section{Badia - memória, história e tradição no Recife}

A Oxum que mais brilhou e redobrou E foi pros braços de Xangô Bem pertinho de Oxalá Nossa terra ela deixou

E no céu foi morar! (Rivaldo Pessoa)

Por meio de Badia é possível se conhecer um pouco mais da prática cultural da gente negra na capital pernambucana, do cotidiano e do processo ritualístico de algumas agremiações carnavalescas e de outras histórias sobre a centenária Recife, que tanto já foi contada e cantada, mas que ainda tem muito a ser narrado dependendo do foco de análise empregado. O historiador Pierre Nora afirmou que "fala-se demais de memória porque ela não existe mais". ${ }^{67}$ De acordo com Aleida Assman, "esta frase atesta a lógica a qual um fenômeno precisa estar perdido, para só então se instalar em definitivo na consciência". ${ }^{68}$ Mas esse processo só se efetua na consciência do grupo que mantém a memória viva. E nesse sentido, é importante esquadrinhar os caminhos desta lembrança ou mesmo deste esquecimento.

A memória dá sentido ao passado a partir das questões que são levantadas no presente. Diante disso, a memória só retira do passado alguns elementos, aqueles que julga pertinente. Se alimentando assim de lembranças vagas e contraditórias. E o historiador, ao se deparar com os "fatos da memória", deve articulá-los com o objetivo de dar inteligibilidade histórica à sua narrativa.

E assim, "os fatos da memória", aprendidos em imagens, apresentando articulações próprias e únicas, estabelecem ligações, ressonâncias com uma teia de acontecimentos, com os quais teremos de operar na construção da narrativa histórica. $^{69}$

Diante disso, o historiador trata o testemunho como um objeto que chega do passado repleto de subjetividades, mas que o ajuda a identificar o que tem sido lembrado e como foi recordado. Não é lugar da história consagrar o que foi louvado pela memória, ao contrário deve buscar uma representação crítica desse passado.

Nesse sentido, a Badia que descrevi nessas linhas não corresponde a uma figura completa em si mesmo, pois não é possível compreender todos os sentidos e significados atribuídos à figura central desse trabalho. A imagem que chegou até nós foi aquela "digna" de ser lembrada pela memória, que retirou do passado alguns elementos, negando ou 
silenciando outros, ressignificando os fatos no presente, com o objetivo de construir uma representação linear e coerente do que foi narrado.

Deve-se pensar na memória como um processo criativo, com uma produção simbólica que institui identidades, e assim poder assegurar a permanência de determinados grupos. Pode-se dizer que em torno da memória social se afirmam poderes de determinada comunidade e de indivíduos sobre si mesmo e sobre os outros.

A memória é a vida, sempre carregada por grupos vivos e, nesse sentido, ela está em permanente evolução, aberta à dialética da lembrança e do esquecimento, inconsciente de suas deformações sucessivas, vulnerável a todos os usos e manipulações, suscetível de longas latências e de repentinas revitalizações. ${ }^{70}$

Já a história pode ser entendida como um campo de possibilidades que aposta na descontinuidade, ela é ao mesmo tempo registro, crítica e reflexão; é narrada e reconstruída a partir de interesses variados. Além de investigar os elementos sublinhados ou mesmo abandonados pela memória. ${ }^{71}$

A história busca uma representação crítica do passado, é uma operação intelectual que critica fontes (entre elas está a memória) e, à luz de uma teoria, realiza uma interpretação do passado enunciando não só consensos, mas também conflitos. Nesse sentido, não serve para glorificar o passado, mas, ao contrário, deslegitima o que foi construído pela memória e que permaneceu escrito e registrado, apresentando-se como um elemento cristalizado. ${ }^{72}$

Assim, ao se trabalhar com as memórias em torno da figura de Maria de Lourdes Silva, não busco construir "a história de Badia", mas sim interpretar como os diversos projetos de memória têm construído "as histórias em torno dela". Pois como alerta Karen Fields, citada por Heide Feldman:

\footnotetext{
"Nuestro esfuerzo intelectual por conseguir el pasado 'real', no el verdadeiro pasado requerido por un presente en particular, no nos autoriza a menospreciar como simplemente equivocada la descomunalmente importante y creativa operación de la memoria que está visible en todas partes. ${ }^{73}$
}

Em torno de Badia foram construídas memórias importantes sobre as práticas nomeadas de negras no Recife que, em muitos momentos, se apresentam como a própria história. Diante disso, quando os recursos históricos são escassos e determinada visão de história precisa ser legitimada, "os trabalhadores da memória" utilizam métodos criativos para inventar tradições que buscam estabelecer uma continuidade com um passado histórico adequado. $^{74}$ 
O lugar de tradição que ocupa Badia estava relacionado à sua ligação com as Tias do Terço. E esse acontecimento, consagrado pela memória, permaneceu escrito, registrado e mantido no presente. Construía uma narrativa harmônica, linear e romântica sobre o passado. No entanto, é preciso ter a consciência de que a memória se constrói na lembrança, mas também no esquecimento.

Em outras palavras, o processo de construção de memórias implica escolhas entre os fatos do passado que, por alguma razão, determinado grupo considera que devam ser lembrados/rememorados; e, ao fazer escolhas, o grupo também sublima, oculta ou esquece outros fatos. Tal aspecto é de fundamental importância para delinearmos a relação entre passado e a história do tempo presente. ${ }^{75}$

Problematizar o lugar de tradição que Badia ocupa na cultura popular e negra do Recife é questionar o natural. As análises sobre essa personagem "apenas" relataram o "lugar do mesmo". Não questionaram os processos de construção dessa tradição. É importante precisar os caminhos dessas escolhas. A proposta não é deslegitimar as tradições, mas compreender os percursos que permitiram sua aceitação, sua permissão e suas continuidades.

Discursos sobre tradição podem ser usados para os mais variados propósitos. Falar de tradição não significa unicamente pensar que o que se faz hoje se fez no passado, mas, fundamentalmente, está ligado ao que espera poder continuar a se fazer no presente e no futuro.

Assim, tradições são relações de poder. Constroem autoridades, determinam legitimidades e tornam memórias processos autênticos do presente. Transformam símbolos recentes em "verdadeiros" elementos de coesão social e de identidade. Discutir tradição é falar de um poder ideológico, com a capacidade de determinar o sentido da realidade, impor valores e narrar a história a partir de sua própria perspectiva. ${ }^{76}$

De acordo com Carlos Sandroni, as discussões em torno de "Tradição" no campo das Ciências Humanas e Sociais foram utilizadas largamente associadas à ideia de "Construcionismo Social". ${ }^{77}$ E esse viés "construcionista" encontrou ecos nos estudos de Hobsbawm e Ranger, em que o termo "Tradição" esteve relacionado ao tema da "Invenção". Assim, "Tradição Inventada" foi definida da seguinte forma pelos autores:

Um conjunto de práticas, normalmente reguladas por regras tácita ou abertamente aceitas; tais práticas, de natureza ritual ou simbólica, visam inculcar certos valores e normas de comportamento através da repetição, o que implica, automaticamente, uma continuidade em relação ao passado. Aliás, sempre que possível, tenta se estabelecer continuidade com um passado histórico apropriado. ${ }^{78}$ 
Diante disso, foi possível a construção de memórias enraizadas na mais remota antiguidade e unidas por laços naturais. $\mathrm{Na}$ esteira dos estudos de Hobsbawm e Ranger, inúmeros outros trabalhos se dedicaram a denunciar o caráter inventado, fabricado das tradições. O apelo ao passado seria, portanto, enganador, ocultando estratégias de dominação.

[...] muitas tradições consideradas antigas e veneráveis possuem na verdade, origens relativamente recentes, devendo a falsa imputação de idade ser compreendida no quadro de uma análise de estruturas de poder e dominação ideológica. ${ }^{79}$

Entretanto, falar em "tradições inventadas" pode parecer redundante, haja vista que os homens estão sempre a criar, recriar, inovar, transformar suas ações em sociedade: "Tradições seriam, por definição, continuamente reinventadas em função das sempre renovadas conjunturas do presente". ${ }^{80}$

Entre as inúmeras "Badias" que a história pode enunciar, uma foi saudada e louvada pela memória e chegou até o presente. As outras foram esquecidas e silenciadas. E nunca é demais repetir, faz-se importante lançar essa história à luz dos conflitos. E com isso, produzir visibilidade dos contornos, nem sempre harmônicos, desse acontecimento.

Apesar das inovações provocadas pelos estudos precursores de Hobsbawm e Ranger, é preciso ir além da "simples" nomeação que as "tradições são inventadas" ou mesmo que as tradições são produtos das ações dos intelectuais. Os atores sociais que produzem as práticas culturais não são passivos ou inertes dentro dos processos de construção das tradições. Eles a significam, a valoram e contribuem para sua afirmação, legitimação e continuidade. Assim, é necessário compreender os caminhos dessa construção.

Não mais, aceita-se um debate acadêmico que tome os praticantes da dita "cultura popular" como ingênuos. Esses sujeitos, em meio às suas comunidades, têm seus desejos, seus anseios, estabelecem negociações e provocam disputas e tensões. Nesse sentido, é que se faz importante compreender porque determinadas figuras, em dado momento histórico escolheram "certa" tradição e quais os mecanismos que permitiram aquela escolha e que deram sustentação para que esta permitisse ainda atuar no presente.

\section{Notas}

\footnotetext{
${ }^{1}$ Maurice Halbwachs afirmou que não existe apenas uma memória coletiva que se opõe a história, mas sim várias memórias. HALBWACHS, Maurice. A Memória Coletiva. São Paulo, Centauro, 2006.
} 


\begin{abstract}
${ }^{2}$ Apesar da multiplicidade de manifestações culturais, usarei a expressão cultura negra por acreditar que ela atenda melhor às compreensões que desejo construir. "Cultura, por se tratar de uma construção dotada de significados intimamente ligados com as 'leituras' do quotidiano. Negra, por entender que, devido à segregação tácita a que foram impostos, os negros e as negras constituíram práticas e costumes que expressam suas visões de mundo, pontos de vista, memórias, sociabilidades, dentre outras questões". LIMA, Ivaldo Marciano de França. Maracatu-nação e grupos percussivos: diferenças, conceitos e histórias. In: GUILLEN, Isabel C. M. (Org.). Inventário cultural dos maracatus nação. Recife PE: EDUFPE - Editora da Universidade Federal de Pernambuco, 2013, v. 01, p. 51.

${ }^{3}$ O popular é um tema recorrente nesses anos. A Fundação de Cultura da Cidade do Recife foi criada em 1979 com o objetivo de trazer de volta ao Carnaval o seu aspecto popular que, segundo parcela da intelectualidade e das autoridades políticas, estava em desuso, cedendo espaço a outras práticas, como a espetacularização. E os membros que dirigiam a Fundação de Cultura da cidade acreditavam que a figura de Badia representaria os contornos da ideia de popular que desejavam construir para a festa.

${ }^{4}$ Ideia de homenagear Badia veio do então presidente da Fundação de Cultura da Cidade do Recife no ano de 1985, Cussy de Almeida, como uma das atividades do retorno ao Carnaval participação na capital pernambucana. Cussy de Almeida foi maestro e professor da Universidade Federal do Rio Grande do Norte e da Universidade Federal da Paraíba. No Recife foi diretor do Conservatório Pernambucano de Musica e da Fundação de Cultura da Cidade do Recife. Faleceu com 74 anos em 2010.

${ }^{5}$ Foliões fazem a festa para a Madrinha das Agremiações. Jornal do Commercio, 9 de fevereiro de 1985, p. 08.

${ }^{6}$ Foliões fazem a festa para a Madrinha das Agremiações. Jornal do Commercio, 9 de fevereiro de 1985, p. 08.

${ }^{7}$ Badia, zeladora dos orixás e dona do Carnaval de 1985. Diário de Pernambuco, 17 de fevereiro de 1985, p. B1 .
\end{abstract}

${ }^{8}$ Utilizo a expressão "simples" tomando por base as discussões feitas por Michel de Certeau quando este dissertou sobre o papel do homem ordinário, pessoas simples, homens comuns que por meio de suas astúcias driblavam as mais variadas situações do cotidiano. Por meio da arte da trampolinagem rompiam com a dominação que lhe apresentava como evidente, davam assim o drible. E em muitas situações o fraco tornava-se forte. Para saber mais ver CERTEAU, Michel. A Invenção do Cotidiano I. Artes de Fazer. Tradução de Ephraim Ferreira Alves. Petrópolis, RJ. Vozes, 1994. P. 109 a 166.

${ }^{9}$ Utilizo a expressão trajetória tal como foi cunhada por Pierre Bourdieu que afirma "[...] a construção da noção de trajetória como série de posições sucessivamente ocupadas por um mesmo agente (ou um mesmo grupo) num espaço que é ele próprio um devir, estando sujeito a incessantes transformações. Tentar compreender uma vida como uma série única e por si suficiente de acontecimentos sucessivos, sem outro vínculo que não a associação a um "sujeito cuja constância certamente não é senão aquela de um nome próprio, é quase tão absurdo quanto tentar explicar a razão de um trajeto no metrô sem levar em conta a estrutura da rede, isto é, a matriz das relações objetivas entre as diferentes estações.". BOURDIEU, Pierre. A Ilusão Biográfica, In: Usos \& Abusos da História Oral. Janaína Amado e Marieta de Moraes Ferreira (Organizadoras). 8a . ed. Rio de Janeiro: Editora FGV, 2006, p. 189-190.

${ }^{10}$ Carnaval do Recife é dedicado a Badia. Dário de Pernambuco, 28 de janeiro de 1985, p. A-9; Badia, zeladora dos orixás e dona do Carnaval de 1985. Diário de Pernambuco, 17 de fevereiro de 1985, p. B-1; Foliões fazem a festa para a Madrinha das Agremiações. Jornal do Commercio, 9 de fevereiro de 1985, p. 08.

${ }^{11}$ É importante destacar que o Pátio do Terço localiza-se em frente à igreja de mesmo nome. Tornou-se um lugar de relevante importância na celebração de práticas negras no Recife. "Essa igreja foi construída por escravos e, segundo alguns historiadores, a área próxima teria sido um cemitério dos negros escravizados". AMARAL, Rita. Mães-de-Santo, mães de tanto. O papel cultural das sacerdotisas dos cultos afro-brasileiros. Os urbanitas Revista de Antropologia Urbana. Ano 4. v. 04. № 6. Dez, 2007. Disponível em: http://www.osurbanitas.org/osurbanitas6/Amaral2007.html. Acesso em 30/03/2015.

12 Xangô é a denominação, em Pernambuco, de práticas religiosas e festivas comumente nomeadas de Candomblé em diversas outras partes do Brasil.

${ }^{13}$ ALMEIDA, Magdalena Maria de. Novas dimensões para a história do Recife. Arrecifes, Recife, 01 dez. 2005.

14 BRANDÃO, Maria do Carmo \& MOTTA, Roberto. Adão e Badia: carisma e tradição no Xangô de Pernambuco, In: Caminhos da Alma. Vagner Gonçalves (Organizador). São Paulo: Summus, 2002, p. 75.

${ }^{15}$ COSTA, V. G. Nação Xambá: criando e recriando estratégias de garantia de espaços sociais e religiosos no Recife. Ciências Humanas em Revista (UFMA), v. 4, p. 11-30, 2006, p. 25.

${ }^{16}$ BRANDÃO, Maria do Carmo \& MOTTA, Roberto. Op. Cit., p. 62.

${ }^{17}$ Idem.

${ }^{18}$ A África funcionou (funciona) durante longo tempo como o lugar da autenticidade nos cultos da religião dos negros e negras no Brasil. Assim, quanto mais africanizado, mais autêntico seria o espaço. 
${ }^{19}$ CAPONE, Stefania. Os Yoruba do Novo Mundo: religião, etnicidade e nacionalismo negro nos Estados Unidos. Rio de Janeiro: Pallas, 2011, p. 25.

20 Sobre isso ver os trabalhos de PEREIRA CAMPOS, Zuleica Dantas. De mãe de santo a mulher: invenção e reinvenção de papéis. Revista Mandrágora, v.17. $N^{o}$. 17, 2011, p. 17-37; e BRANDÃO, Maria do Carmo \& MOTTA, Roberto. Op. Cit., 2002.

21 "Adão nasceu no Recife, em 1877. Seu nome oficial era Felipe Sabino da Costa. Como e por que veio a chamar-se Adão não consta dos muitos documentos e depoimentos que conseguimos reunir. Era filho de certo Sabino da Costa [...] diz ter sido escravo e que, segundo outros depoimentos, seria natural da África, mais especificamente em Lagos, na Nigéria. Adere ao Sítio, então chefiado por Inês Joaquina da Costa, que todos os depoimentos apontam como fundadora desse terreiro. Mora algum tempo em Maceió e talvez também em Salvador. Passa algum tempo na África. Retorna ao Recife. Assume ou retoma a chefia do Sítio. Transforma-se no que vem a ser virtualmente o principal terreiro afro-recifense. Mas faz também do Sítio um centro de devoções católicas. Morre em 26 de março de 1936". BRANDÃO, Maria do Carmo \& MOTTA, Roberto. Op. Cit., p. 56.

22 "O termo fundamento, como é do conhecimento geral de devotos e estudiosos, significa, em linguagem afrobrasileira (sic), a justificação, a base, o alicerce simbólico de um rito, de uma crença ou de um terreiro". Ibidem, pp. $75-76$.

Sobre os estudos do Xangô no Recife ver FERNANDES, Gonçalves. Xangôs do Nordeste. Rio de Janeiro, Civilização Brasileira, 1937; MELLO, José Antônio Gonçalves de. População Negra e Cultos Africanos, In: MELlO, José Antônio Gonçalves de. Diário de Pernambuco: economia e sociedade no $2^{o}$ reinado. Recife: Editora Universitária da UFPE, 1996; MELLO, José Antônio Gonçalves de. Um governador colonial e as seitas africanas, In: José Antônio Gonçalves de Mello. Tempo de Jornal. Leonardo Dantas Silva (Org.). pp. 41-46. Publicado originalmente no Diario de Pernambuco em 22 de janeiro de 1950; CAVALCANTI, Pedro. As Seitas Africanas do Recife, In: PINTO, Roquete et al. Estudos Afro Brasileiros. Rio de Janeiro, Ariel, 1935; CAMPOS, Zuleica Dantas Pereira. O combate ao Catimbó: Práticas repressivas às religiões afro umbandistas nos anos trinta e quarenta. Tese (Doutorado em História). Recife: Universidade Federal de Pernambuco, 2001.

${ }^{24}$ BRANDÃO, Maria do Carmo \& MOTTA, Roberto. Op. Cit., p. 50.

${ }^{25}$ CAPONE, Stefania. Op. Cit., p. 26.

${ }^{26}$ Gilroy, Paul. O Atlântico Negro. Modernidade e dupla consciência, São Paulo, Rio de Janeiro, 34/Universidade Cândido Mendes - Centro de Estudos Afro-Asiáticos, 2001.

${ }^{27}$ MATTOS, H. ou CASTRO, H. M. M. Resenha de O Atlântico Negro - Modernidade e Dupla Consciência de Paul Gilroy. Estudos Afro-Asiáticos, Rio de Janeiro, v. ano 24, n.2, p. 409-414, 2002.

${ }^{28}$ HERSKOVITS, Melville J. The Myth of Negro Past. Boston: Beacon Press. Boston: Beacon Press, 1990.

${ }^{29}$ CAPONE, Stefania. Op.Cit., p. 28

${ }^{30}$ WADE, Peter. “Compreendendo a 'África' e a 'negritude' na Colômbia: a música e a política da cultura”. Rio de Janeiro, Estudos Afro-Asiáticos, Ano 25, n.1, 2003, p. 150.

${ }^{31}$ MINTZ, Sidney W.; Price, Richard. O Nascimento da Cultura Afro-Americana. Rio de Janeiro, Pallas, Centro de Estudos Afro-Bras. 2003.

${ }^{32}$ WADE, Peter. Op. Cit., p. 150.

${ }^{33}$ WADE, Peter. Op. Cit., p. 153

${ }^{34}$ SANSONE, Lívio. Da áfrica ao afro: uso e abuso da áfrica entre os intelectuais e na cultura popular brasileira durante o século XX. Afro-Ásia, 27, 2002, p. 249.

${ }^{35}$ BRANDÃO, Maria do Carmo \& MOTTA, Roberto. Op. Cit., p. 66.

${ }^{36}$ Valdeck Mello é um sambista do Recife. Durante muitos anos frequentou a casa de Badia. É um dos fundadores da escola Estudantes de São José, e a qual presidiu durante muitos anos. Atualmente é presidente da Federação das Escolas de Samba de Pernambuco (FESAPE). A entrevista em questão foi concedida aos pesquisadores Ester Monteiro e Salviano Feitosa em 16 de abril de 2010 e encontra-se disponível no acervo da Casa do Carnaval, localizada no Pátio de São José, no Recife.

${ }^{37}$ Música "Mãe Badia", de Rivaldo Pessoa. Disponível em: http://negrospe.blogspot.com.br/2013/08/badia.html Acesso em 01/04/2015.

${ }^{38}$ Para Roger Chartier “As Representações não são discursos neutros: produzem estratégias e práticas tendentes a impor uma autoridade, uma deferência, e mesmo a legitimar escolhas". E continua: "As representações são variáveis segundo as disposições dos grupos ou classes sociais; aspiram à universalidade, mas são sempre determinadas pelos interesses dos grupos que as forjam. O poder e a dominação estão sempre presentes". CHARTIER, Roger. A História Cultural: entre práticas e representações. Tradução de Maria Manuela Galhardo. 2. Ed. Lisboa: Difel, 2002, p. 17.

${ }^{39}$ AMARAL, Rita. "Mães-de-Santo", 2007. 
${ }^{40}$ LIMA, Ivaldo Marciano França. Entre Pernambuco e África. História dos Maracatus-nação do Recife e a espetacularização da cultura popular (1960 - 2000). Tese de Doutoramento em História, UFF, Niterói, Rio de Janeiro, 2010.

${ }^{41}$ GUILLEN, Isabel C. M. Rainhas Coroadas: história e ritual nos maracatus nação do Recife, In: GUILLEN, Isabel. C. M. \& LIMA, I. M. F. Cultura Afro descendente no Recife: Maracatus, valentes e catimbós. Recife: Bagaço, 2007, p. 185.

${ }^{42}$ GUILLEN, Isabel C. M. Op. Cit., p. 185.

${ }^{43}$ GUILLEN, Isabel C. M. Op. Cit., p. 186.

${ }^{44}$ BRANDÃO, Maria do Carmo \& MOTTA, Roberto. Op. Cit., p. 68.

${ }^{45}$ BRANDÃO, Maria do Carmo \& MOTTA, Roberto. Op. Cit., p. 72.

46 PEREIRA CAMPOS, Zuleica Dantas. Das tias do pátio do terço a noite dos tambores silenciosos: espetacularização dos xangôs do recife pelos maracatus e afoxés. Anais do XI Congresso Luso Afro Brasileiro de Ciências Sociais - Diversidades e (Des) Igualdades. UFBA: Salvador, 2011, p. 12.

${ }^{47}$ Entrevista realizada pelos pesquisadores Ester Monteiro e Salviano Feitosa em 16 de abril de 2010 com o senhor Valdeck Mello. O material encontra-se disponível no acervo da Casa do Carnaval localizada no Pátio de São José, no Recife.

${ }^{48}$ Raminho de Oxossi é um famoso babalorixá pernambucano, conhecido por celebrar cultos aos eguns, principalmente no evento da Noite dos Tambores Silenciosos. Foi iniciado no Xangô por Badia (sua mãe de santo) no Pátio do Terço. Atualmente, Raminho de Oxossi lidera um terreiro em Jardim Brasil - Olinda (PE).

${ }^{49}$ PEREIRA CAMPOS, Zuleica Dantas. Op. Cit., 2011, p. 10.

${ }^{50}$ SANTOS, J. T. O poder da cultura e a cultura no poder. A disputa simbólica da herança cultural negra no Brasil. 1. ed. Salvador: Edufba, 2005. v. 01.

${ }^{51}$ BOURDIEU, Pierre. O poder simbólico. Tradução Fernando Tomaz, 10. ed. Rio de Janeiro: Bertrand Brasil, 2007.

${ }^{52}$ ALMEIDA, Magdalena Maria de. Op. Cit.

${ }^{53}$ Sobre isso ver a dissertação SILVA. A. N. "Quem gosta de samba, bom pernambucano não é?". Recife: Universidade Federal de Pernambuco (Mestrado em História), 2011.

${ }^{54}$ Carnaval do Recife é dedicado a Badia. Diário de Pernambuco, 29 de janeiro de 1985, p. A-9; Badia receberá título da folia. Diário de Pernambuco, 31 de janeiro de 1985, p. A-8.

${ }_{55}$ Carnaval de Badia, melhor do país. Diário de Pernambuco, 03 de fevereiro de 1985, p. A-14.

56 "A denominação dos clubes e troças - não de todos, mas de um conjunto no qual se incluíam os que alcançaram maior popularidade - evocava o mundo cotidiano do trabalho, especialmente do trabalho manual, fosse enquanto atividade, fosse enquanto instrumento: Caiadores, Vassourinhas, Pás, Espanadores, Abanadores, Vasculhadores, Lenhadores, Empalhadores, Ciscadores [...] Isso não queria dizer que seus componentes fossem necessariamente trabalhadores da categoria indicada no frontispício do estandarte. O fundamental era que os nomes dos clubes e troças carnavalescos remetiam ao universo do trabalho, na sua fração manual: das artes e ofícios, dos operários e dos empregados no comércio.". ARAÚJO, Rita de Cássia Barbosa. Festas: máscaras do tempo - entrudo, mascarada e frevo no carnaval do Recife. Fundação de Cultura da Cidade do Recife, 1996, pp. 348-349.

${ }^{57}$ Badia, zeladora dos orixás e dona do Carnaval de 1985. Diário de Pernambuco, 17 de fevereiro de 1985, p. B1.

58 Idem.

${ }^{59}$ Idem.

${ }^{60}$ Idem.

${ }^{61}$ Agremiações de São José debatem homenagem à Badia. Diário de Pernambuco, 01 de fevereiro de 1985, p. A-8.

${ }^{62}$ São José concentra desfile. Diário de Pernambuco, 10 de fevereiro de 1985, p. A-18.

${ }^{63}$ Idem.

${ }^{64}$ Carnaval de Badia, melhor do país. Diário de Pernambuco, 03 de fevereiro de 1985, p. A-14.

${ }^{65}$ Badia, zeladora dos orixás e dona do Carnaval de 1985. Diário de Pernambuco, 17 de fevereiro de 1985, p. B1

${ }^{66}$ Badia recorda a alegria dos carnavais passados. Jornal do Commercio, 21 de fevereiro de 1985, p. 08.

${ }^{67}$ NORA, Pierre. Entre a História e a Memória. A problemática dos lugares. Projeto História. São Paulo, n. 10, 1993, p. 09.

68 ASSMAN, Aleida. Espaços da Recordação: formas e transformação da memória cultural. Tradução Paulo Soethe. Campinas, SP: Editora da UNICAMP, 2011, p. 15.

${ }^{69}$ GUIMARÃES NETO, Regina Beatriz. Cidades da Mineração: memórias e práticas culturais - Mato Grosso na Primeira metade do século XX. Cuiabá-MT: Carlini \& Caniato; EdUFMT, 2006, p. 48. 


\footnotetext{
${ }^{70}$ NORA, Pierre. Op. Cit., p. 19.

${ }^{71}$ FERREIRA, M. M. História, Memória e Tempo Presente, In: Novos Domínios da História. Ciro Flamarion Cardoso \& Ronaldo Vainfas (Orgs). Rio de Janeiro: Elsevier, 2012, p. 25.

${ }^{72}$ FERREIRA, M. M. Op. Cit., p. 26.

${ }^{73}$ FIELDS, Karen. "What One Cannot Remember Mistakenly". In: History \& Memory in AfricanAmerican Culture. Geneviève Fabre e Robert O' Meally (eds). New York y Oxford: Oxford University Press, pp. 150-163. Apud: FELDMAN, Heidi Carolyn. Ritmos Negros Del Peru. Reconstruyendo a herencia musical africana. Lima, Instituto de Etnomusicologia/Instituto de Estudos Peruanos, 2009, p. 14.

${ }^{74}$ Sobre isso ver FELDMAN, Heidi Carolyn. Op. Cit. p. 13.

${ }^{75}$ FERREIRA, M. M. Op. Cit., p. 27.

${ }^{76}$ COUTINHO, Eduardo Granja. Velhas Histórias, memórias futuras: o sentido da tradição em Paulinho da Viola. 2. ed. ver. e ampl. Rio de Janeiro: Eidtora da UFRJ, 2011, p. 34.

${ }^{77}$ SANDRONI, Carlos. Tradições e suas controvérsias no Maracatu de Baque Virado, In: GUILLEN, Isabel. C. M. (Org.). Inventário Cultural dos Maracatus. Recife: Ed. da UFPE, 2013.

${ }^{78}$ HOBSBAWM, Eric \& RANGER, Terence (Orgs.). A Invenção das Tradições. Rio de Janeiro: Paz e Terra, 2006.

${ }^{79}$ SANDRONI, Carlos. Op. Cit., p. 28.

${ }^{80}$ SANDRONI, Carlos. Op. Cit., p. 30.
}

\section{Referências Bibliográficas}

ALMEIDA, Magdalena Maria de. Novas dimensões para a história do Recife. Arrecifes, Recife, 01 dez. 2005.

AMARAL, Rita. Mães-de-Santo, mães de tanto. O papel cultural das sacerdotisas dos cultos afro-brasileiros. Os urbanitas - Revista de Antropologia Urbana. Ano 4. v. 04. No. 6. Dez, 2007.

ARAÚJO, Rita de Cássia Barbosa. Festas: máscaras do tempo - entrudo, mascarada e frevo no carnaval do Recife. Fundação de Cultura da Cidade do Recife, 1996, pp. 348-349.

ASSMAN, Aleida. Espaços da Recordação: formas e transformação da memória cultural. Tradução Paulo Soethe. Campinas, SP: Editora da UNICAMP, 2011.

BOURDIEU, Pierre. A Ilusão Biográfica, In: Usos \& Abusos da História Oral. Janaína Amado e Marieta de Moraes Ferreira (Organizadoras). 8 ${ }^{\text {a }}$. ed. Rio de Janeiro: Editora FGV, 2006.

BOURDIEU, Pierre. O poder simbólico. Tradução Fernando Tomaz, 10. ed. Rio de Janeiro: Bertrand Brasil, 2007.

BRANDÃO, Maria do Carmo \& MOTTA, Roberto. Adão e Badia: carisma e tradição no Xangô de Pernambuco, In: Caminhos da Alma. Vagner Gonçalves (Organizador). São Paulo: Summus, 2002.

CAMPOS, Zuleica Dantas Pereira. O combate ao Catimbó: Práticas repressivas às religiões afro umbandistas nos anos trinta e quarenta. Tese (Doutorado em História). Recife: Universidade Federal de Pernambuco, 2001.

CAPONE, Stefania. Os Yoruba do Novo Mundo: religião, etnicidade e nacionalismo negro nos Estados Unidos. Rio de Janeiro: Pallas, 2011.

CAVALCANTI, Pedro. As Seitas Africanas do Recife, In: PINTO, Roquete et al. Estudos Afro Brasileiros. Rio de Janeiro, Ariel, 1935.

CERTEAU, Michel. A Invenção do Cotidiano I. Artes de Fazer. Tradução de Ephraim Ferreira Alves. Petrópolis, RJ. Vozes, 1994.

CHARTIER, Roger. A História Cultural: entre práticas e representações. Tradução de Maria Manuela Galhardo. 2. Ed. Lisboa: Difel, 2002. 
COSTA, V. G. Nação Xambá: criando e recriando estratégias de garantia de espaços sociais e religiosos no Recife. Ciências Humanas em Revista (UFMA), v. 4, p. 11-30, 2006.

COUTINHO, Eduardo Granja. Velhas Histórias, memórias futuras: o sentido da tradição em Paulinho da Viola. 2. ed. ver. e ampl. Rio de Janeiro: Eidtora da UFRJ, 2011.

FERNANDES, Gonçalves. Xangôs do Nordeste. Rio de Janeiro, Civilização Brasileira, 1937.

FERREIRA, M. M. História, Memória e Tempo Presente, In: Novos Domínios da História. Ciro Flamarion Cardoso \& Ronaldo Vainfas (Orgs). Rio de Janeiro: Elsevier, 2012.

FIELDS, Karen. "What One Cannot Remember Mistakenly". In: History \& Memory in AfricanAmerican Culture. Geneviève Fabre e Robert O' Meally (eds). New York y Oxford: Oxford University Press, Apud: FELDMAN, Heidi Carolyn. Ritmos Negros Del Peru. Reconstruyendo a herencia musical africana. Lima, Instituto de Etnomusicologia/Instituto de Estudos Peruanos, 2009.

Gilroy, Paul. O Atlântico Negro. Modernidade e dupla consciência, São Paulo, Rio de Janeiro, 34/Universidade Cândido Mendes - Centro de Estudos Afro-Asiáticos, 2001.

GUILLEN, Isabel C. M. Rainhas Coroadas: história e ritual nos maracatus nação do Recife, In: GUILLEN, Isabel. C. M. \& LIMA, I. M. F. Cultura Afro descendente no Recife: Maracatus, valentes e catimbós. Recife: Bagaço, 2007, p. 185.

GUIMARÃES NETO, Regina Beatriz. Cidades da Mineração: memórias e práticas culturais - Mato Grosso na Primeira metade do século XX. Cuiabá-MT: Carlini \& Caniato; EdUFMT, 2006.

HALBWACHS, Maurice. A Memória Coletiva. São Paulo, Centauro, 2006.

HERSKOVITS, Melville J. The Myth of Negro Past. Boston: Beacon Press. Boston: Beacon Press, 1990.

HOBSBAWM, Eric \& RANGER, Terence (Orgs.). A Invenção das Tradições. Rio de Janeiro: Paz e Terra, 2006.

LIMA, Ivaldo Marciano de França. Maracatu-nação e grupos percussivos: diferenças, conceitos e histórias. In: GUILLEN, Isabel C. M. (Org.). Inventário cultural dos maracatus nação. Recife PE: EDUFPE - Editora da Universidade Federal de Pernambuco, 2013.

LIMA, Ivaldo Marciano França. Entre Pernambuco e África. História dos Maracatus-nação do Recife e a espetacularização da cultura popular (1960 - 2000). Tese de Doutoramento em História, UFF, Niterói, Rio de Janeiro, 2010.

MATTOS, H. ou CASTRO, H. M. M. Resenha de O Atlântico Negro - Modernidade e Dupla Consciência de Paul Gilroy. Estudos Afro-Asiáticos, Rio de Janeiro, v. ano 24, n.2, p. 409414, 2002.

MELLO, José Antônio Gonçalves de. População Negra e Cultos Africanos, In: MELLO, José Antônio Gonçalves de. Diário de Pernambuco: economia e sociedade no $2^{o}$ reinado. Recife: Editora Universitária da UFPE, 1996.

MINTZ, Sidney W.; Price, Richard. O Nascimento da Cultura Afro-Americana. Rio de Janeiro, Pallas, Centro de Estudos Afro-Bras. 2003.

NORA, Pierre. Entre a História e a Memória. A problemática dos lugares. Projeto História. São Paulo, n. 10, 1993.

PEREIRA CAMPOS, Zuleica Dantas. Das tias do pátio do terço a noite dos tambores silenciosos: espetacularização dos xangôs do recife pelos maracatus e afoxés. Anais do XI Congresso Luso Afro Brasileiro de Ciências Sociais - Diversidades e (Des) Igualdades. UFBA: Salvador, 2011.

PEREIRA CAMPOS, Zuleica Dantas. De mãe de santo a mulher: invenção e reinvenção de papéis. Revista Mandrágora, v.17. No. 17, 2011. 
SANDRONI, Carlos. Tradições e suas controvérsias no Maracatu de Baque Virado, In: GUILLEN, Isabel. C. M. (Org.). Inventário Cultural dos Maracatus. Recife: Ed. da UFPE, 2013.

SANSONE, Lívio. Da África ao afro: uso e abuso da África entre os intelectuais e na cultura popular brasileira durante o século XX. Afro-Ásia, 27, 2002.

SANTOS, J. T. O poder da cultura e a cultura no poder. A disputa simbólica da herança cultural negra no Brasil. 1. ed. Salvador: Edufba, 2005.

WADE, Peter. 'Compreendendo a 'África' e a 'negritude' na Colômbia: a música e a política da cultura”. Rio de Janeiro, Estudos Afro-Asiáticos, Ano 25, n.1, 2003. 